\title{
АНАЛИЗ ДИСПРОПОРЦИЙ ФИНАНСОВОГО ОБЕСПЕЧЕНИЯ ИНВЕСТИЦИОННЫХ ПРОЦЕССОВ В ЦФО
}

\section{ANALYSIS OF DISPROPORTIONS IN THE FINANCIAL SUPPORT OF INVESTMENT PROCESSES IN THE CENTRAL FEDERAL DISTRICT \\ K. Pozdnyakov}

Summary. The article provides an assessment of the regional concentration of investments in the regions of the Central Federal District in 2010-2019. The main indicators of the investment process and innovation activity in the field of investment use are analyzed. For statistical evaluation of state statistics data in the regional context, the author used statistical methods of analysis (index method, time series analysis). It is concluded that during the study period, the concentration of investments in the Central Federal District remained at a high level: up to $70 \%$ of the district's investments are concentrated in Moscow and the Moscow region. The share of 16 regions of the district accounts for $31.1 \%$ or 1760877 million rubles, but even in this cohort there is a significant gap between the leaders (Tula Region and other regions of the Central Chernozem District) and outsider regions (Kostroma, Ivanovo, Oryol regions). The values of the indices of all indicators in the regions of the district show periodic fluctuations, which is consistent with periods of volatility in the national economy. The probability of alignment in the geographical distribution of fixed capital investments in the regions of the Central Federal District in the medium term is low.

Keywords: finance, investment process, investment in fixed assets, R \& D, innovation, Central Federal District.
Поздняков Константин Константинович К.э.н., доцент, Финансовый университет при Правительстве РФ (Москва) KKPozdnyakov@fa.ru

Аннотация. В статье дана оценка региональной концентрации инвестиций в регионах ЦФ0 в 2010-2019 годах. Проанализированы основные показатели инвестиционного процесса и инновационной активности в сфере использования инвестиций. Для статистической оценки данных государственной статистики в региональном разрезе автором использованы статистические методы анализа (индексный метод, анализ временных рядов). (делан вывод, что за исследуемый период концентрация инвестиций в ЦФ0 осталась на высоком уровне: до 70\% инвестиций округа сосредоточено в Москве и Московской области. На долю 16 регионов округа приходится доля в 31,1\% или 1760877 млн. рублей, но даже в этой когорте значителен отрыв лидеров (Тульская область и иные регионы Центрально-черноземного округа) от регионов-аутсайдеров (Костромская, Ивановская, Орловская области). Значения индексов всех показателей в регионах округа демонстрируют периодические колебания, что согласуется с периодами волатильности в национальной экономике. Вероятность выравнивания в географическом распределении инвестиций в основной капитал в регионах ЦФ0 в среднесрочной перспективе является низкой.

Ключевые слова: финансы, инвестиционный процесс, инвестиции в основной капитал, НИОКР, инновации, ЦФО.

COVID-продолжился рост неопределенности и ухудшение ожиданий в отношении экономической конъюнктуры и инвестиционных перспектив [3]. Согласно данным Росстата, снижение ВВП в 2020 году составило 3,1\% к уровню 2019 года. Инвестиции в основной капитал в 2020 году составили 20,118 трлн. рублей [3], снизившись по сравнению с 2019 годом на полтора пункта. При сохранении негативных трендов до конца 2021 года мы увидим дальнейший отрицательный рост как экономики, так и инвестиций. Данный прогноз находит свое отражение в ожиданиях бизнеса - ухудшение инвестиционного климата в ближайшие годы России ожидают более 50\% крупных и средних компаний [4].

Наблюдаемая динамика показателей инвестиций исключает не только форсированный, но и закономерный социально-экономический рост для России. Стра- 
Таблица 1. Показатели инвестиционного процесса и активности в сфере использования инвестиций в регионе, избранные для целей анализа

\begin{tabular}{|l|l|}
\hline № & Показатели \\
\hline 1.1 & Объем инвестиций в основной капитал (млн. рублей) \\
\hline 1.2 & Объем инвестиций в основной капитал в расчете на душу населения (рублей) \\
\hline 1.3 & Отношение объема инвестиций в основной капитал к валовому региональному продукту (\%) \\
\hline 1.4 & Инвестиции в основной капитал по формам собственности (\%) \\
\hline 1.5 & Доля внутренних затрат на исследования и разработки, в\% к валовому региональному продукту (ВРП) \\
\hline 1.6 & Доля затрат на инновационную деятельность, в общем объеме отгруженных товаров, выполненных работ, услуг (\%) \\
\hline 1.7 & Удельный вес инновационных товаров, работ, услуг в общем объеме отгруженных товаров, выполненных работ, услуг (\%) \\
\hline
\end{tabular}

тегически значимые для нашей страны 3-4\% ежегодного роста [2] требуют увеличения доли инвестиций в ВВП на $7-8 \%$.

Ключевым фактором успешного решения ряда задач роста инвестиционной и инновационной активности, устранения неоднородности российских территорий и повышения качества жизни населения становится региональная политика [5]. Прорыв в экономическом развитии страны невозможен без значительного притока инвестиций как в передовые, так и в отстающие субъекты РФ.

За последние десятилетия в регионах России накоплен обширный опыт решения проблем экономического развития, который следует изучать, переосмысливать и обобщать. Анализ работ, посвященных теории инвестиционного рынка и инвестиционному моделированию, позволяет выделить два основных исследовательских направления [7]: исследования, развивающие общие положения экономической теории, а именно исследование экономического баланса и экономического роста; экономико-статистические исследования инвестиционных процессов.

Обобщение и систематизация научных исследований по различным аспектам статистического измерения инвестиционной привлекательности и развития регионов свидетельствуют о существовании целого комплекса недостаточно изученных проблем в оценке результативности реализации региональной инвестиционной политики [5]. Своевременным и важным представляется статистическое исследование уровня концентрации региональных инвестиций на уровне федеральных округов.

Центральный федеральный округ (ЦФО) как центр притяжения инвестиций России обеспечивает 25-28\% удельного веса всех инвестиций в основной капитал в РФ. При этом в округе к числу успешно развивающихся относятся не более 3-5 регионов. Предварительный анализ показал наличие диспропорций финансового обеспечения инвестиционных процессов в ЦФО, что обуславливает необходимость получения более точных оценок инвестиционной активности в округе.

\section{Шель исслеАования}

Целью исследования является статистический анализ инвестиций в основной капитал и ряда иных показателей инновационного развития в регионах ЦФО за период 2010-2019 гг. для выявления диспропорций в финансировании инвестиционного процесса в округе.

\section{Metos}

Портер предложил понимать конкурентоспособность и инвестиционную привлекательность страны как продуктивность использования ее ресурсов [6]. Мы будем учитывать это определение при оценке инвестиций в НИОКР и инновационную деятельность, а также ее результатов как индикаторов активности в сфере использования инвестиций.

Методами исследования являются статистические методы анализа (индексный метод, анализ временных рядов), методы системного и логического анализа. Статистический массив исследования основан на данных государственной статистики за 2010-2019 гг., опубликованных на официальном сайте Федеральной службы государственной статистики, в том числе в сборниках «Регионы России. Социально-экономические показатели. Инвестиции» [8-13]. Сбор и предобработка данных были сделаны вручную на сайте https://rosstat.gov.ru/. Расчеты и визуализация динамики показателей реализована в Microsoft Excel 2016. Состав анализируемых показателей представлен в таблице 1.

\section{Результаты}

В 2019 году в основной капитал ЦФО было направлено 5662682 млн. руб. в виде инвестиций (рисунок 1). Прирост данного показателя по отношению к уровню 2010 года составил более 111,1\% (3562858 млн. руб.). 


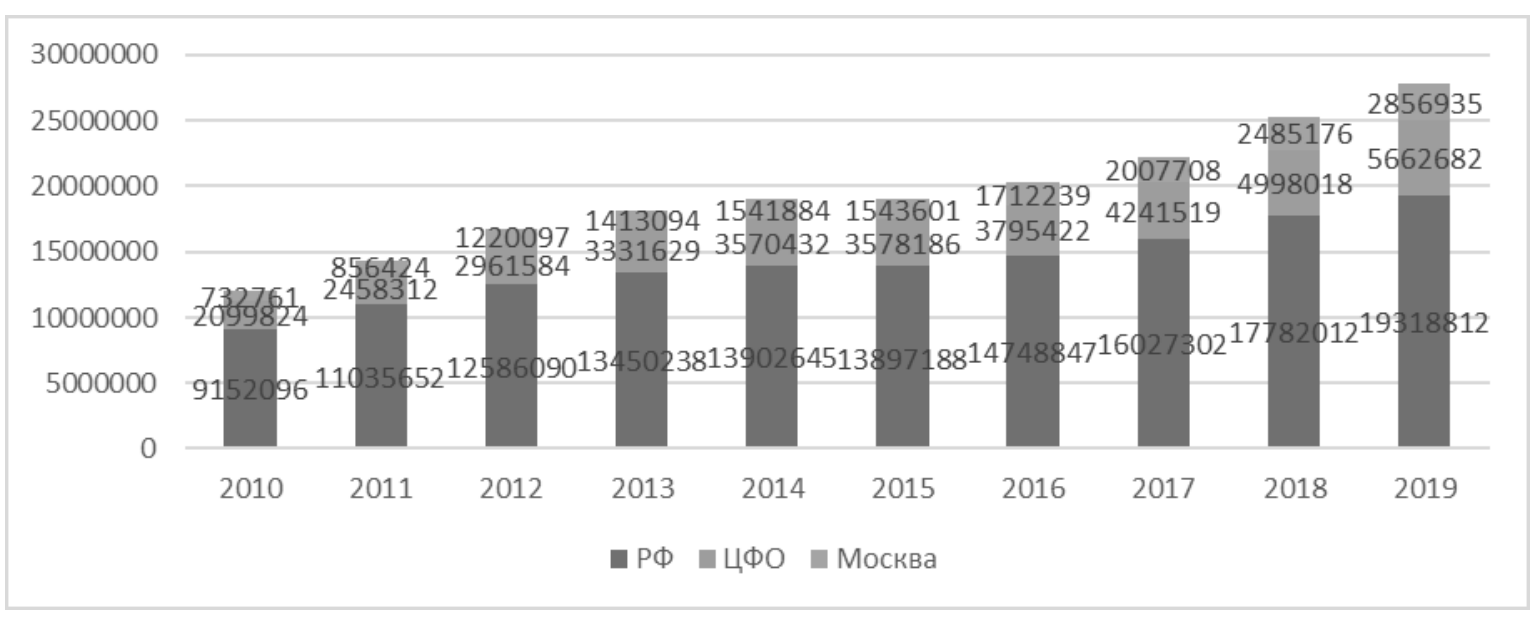

Рис. 1. Динамика инвестиций в основной капитал в фактически действующих ценах (млн. рублей), 2010-2019гг.

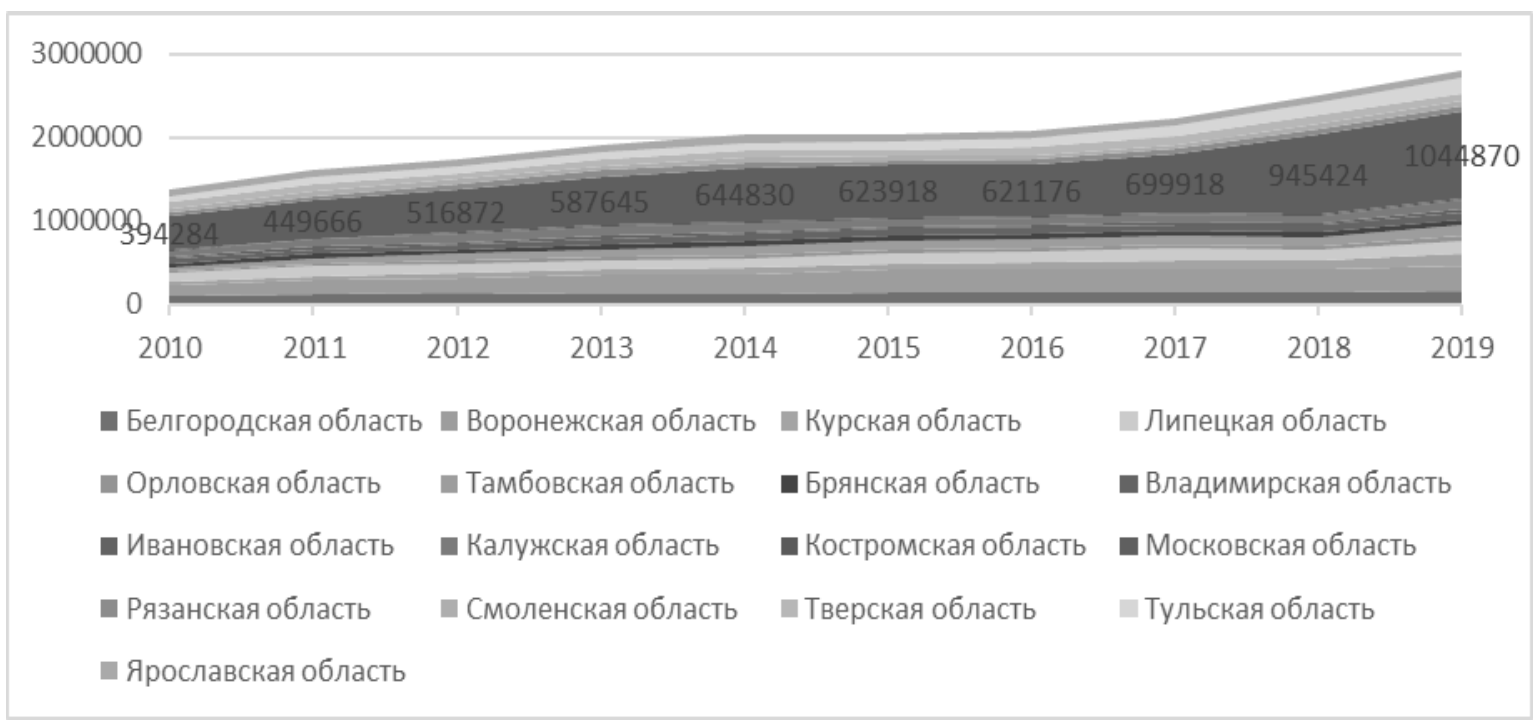

Рис. 2. Динамика инвестиций в основной капитал в фактически действующих ценах, регионы ЦФО (без Москвы)

Средний ежегодный прирост составил 12\% (что выше данного показателя по Российской Федерации на 3\%). ЦФО - лидер России по абсолютным объемам инвестиций. В 2019 году его доля в объеме инвестиций в РФ составила $29,3 \%$, что больше на $6,4 \%$, чем в 2010 году. Москва заняла лидирующую позицию по показателю инвестиций в основной капитал в 2019 году, обеспечив экономике округа инвестиции в размере 2856935 млн. рублей или 50,5\%.

Почти пятую часть инвестиций округа составляют инвестиции Московской области (1044870 млн. рублей), которая занимает 2-е место в нашем рейтинге (рис. 2).
На долю 16 регионов округа приходится доля в 31,1\% или 1760877 млн. рублей. Таким образом, с многократным отставанием от Москвы и Московской области третье, четвертое и пятое места по показателю абсолютного объема инвестиций в основной капитал занимают Воронежская область (298024 млн. рублей), Тульская область (177724 млн. рублей) и Белгородская область (167367 млн. рублей). Аутсайдерами региона в 2019 году стали Костромская (26194 млн. рублей), Ивановская (37992 млн. рублей) и Орловская области (55877 млн. рублей).

В Центрально-черноземном регионе (ЦЧР) по показателю абсолютной величины инвестиций в основной 
Таблица 2. Инвестиции в основной капитал на душу населения, РФ и ЦФО (рубли)

\begin{tabular}{|l|l|l|l|l|l|}
\hline & $\mathbf{2 0 1 0}$ & $\mathbf{2 0 1 9}$ & $\mathbf{2 0 2 0}$ & $\begin{array}{l}\mathbf{2 0 2 0} \\
\text { к 2010,\% }\end{array}$ & абс. прирост \\
\hline Российская Федерация & 64068 & 131701 & 137364 & 17,3 & 129415 \\
\hline ЦФО & 54697 & 154631 & 159540 & 20,1 & 151584 \\
\hline
\end{tabular}

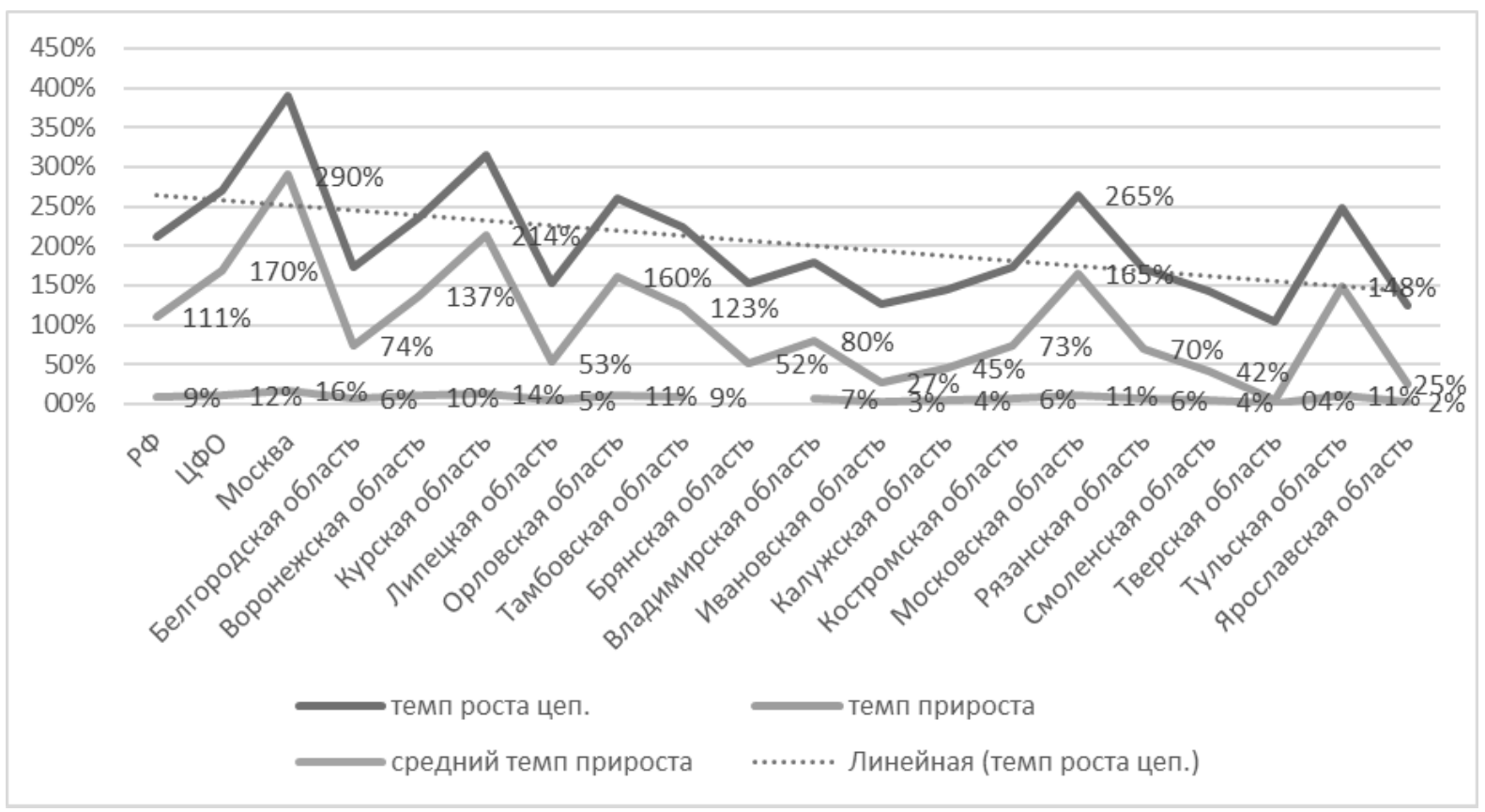

Рис. 3. Темпы роста, прироста и средний темп прироста инвестиций в основной капитал в регионах ЦФО, 2010-2019 гг.

капитал лидирует Воронежская область - 298 млн. рублей или 33,9\%, или в общем объеме инвестиций ЦчМ (рисунок 2). По абсолютным показателям аутсайдером макрорегиона стала Орловская область (55877 млн. руб.), оторвавшаяся от лидера на -242 млн. руб. (более чем 5-кратный отрыв).

В Центральном регионе к порогу в 100 млрд. рублей инвестиций помимо упомянутой выше Тульской области, подошли Калужская, Ярославская и Владимирская области с показателями в 108251, 90094 и 90085 млн. рублей соответственно. 86252 млн. рублей инвестиций обеспечила экономике региона Тверская область. Костромская область с 18-й позицией в рейтинге субъектов РФ по абсолютному показателю инвестиций в основной капитал в 2019 году отстает от лидера Центрального региона (Тульская область) в 6,8 раз, а от Воронежской области - в 11,5 раз.

На рисунке 3 представлены темпы роста и прироста инвестиции в основной капитал по субъектам РФ. Расчеты автора показывают, что в 2010-2019 гг. все реги- оны ЦФО продемонстрировали отрицательные темпы прироста при положительных темпах роста.

Наиболее низкие показатели среднего прироста инвестиций на уровне 2-3\% демонстрируют аутсайдеры - Ярославская и Ивановская области. Средний прирост инвестиций на уровне 4-5\% у Калужской, Смоленской, Тверской, Липецкой области. Инвестиции Белгородской, Владимирской, Костромской, Рязанской областей прирастали в среднем на 6-7\% в год. Лидерами по показателям среднего темпа прироста ожидаемо стали Москва (16\%), которая «росла» быстрее РФ и ЦФО, Московская область (11\%) и Курская область (14\%). Равными темпами с Московской областью росли инвестиции Тульской и Орловской областей (11\%).

Инвестиции в основной капитал на душу населения в РФ и ЦФО в 2010-2019 годах, а также их динамика представлены в таблице 2. По показателю абсолютной величины инвестиций в основной капитал на душу населения лидируют Москва (281657 рублей) и Московская область (142668 рублей). Показатели Москвы 


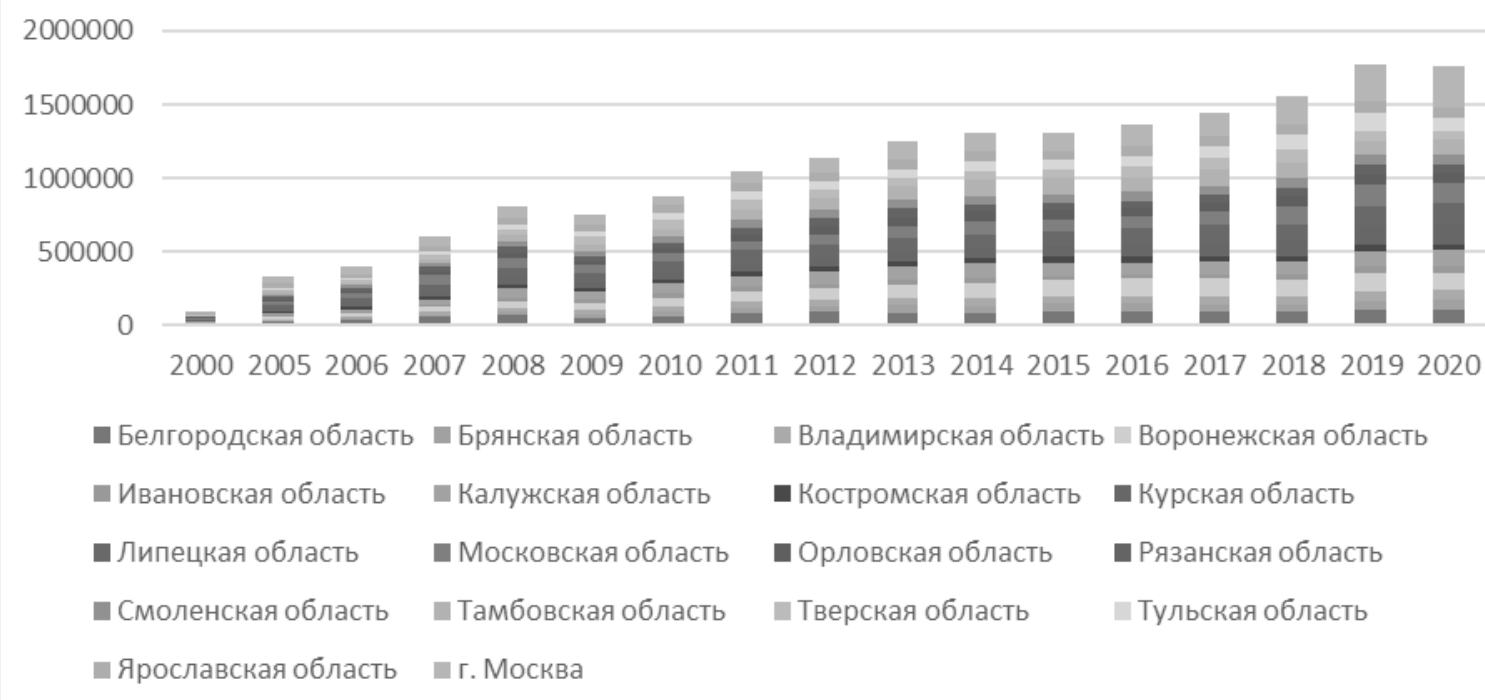

Рис. 4. Инвестиции в основной капитал на душу населения в регионах ЦФО, 2010-2019 гг. (рубли)

почти в два раза больше аналогичных показателя РФ (131702 рублей) и почти в четыре раза больше показателя ЦФО (54697 рублей).

Помимо Москвы и Московской области (рис. 4) в Центральном регионе отметку в 100000 рублей инвестиций на душу населения превысили только Тульская область (120698 рублей) и Калужская область (111841 рублей). Из шести областей Центрально-черноземного региона четыре - инвестировали на уровне 108-135 тыс рублей на душу населения. Лидер ЦЧР по показателю абсолютной величины инвестиций в основной капитал на душу населения - Липецкая область (135796 руб., прирост - 102345 руб.), однако, по абсолютному приросту и темпам роста регион уступает другим регионам ЦЧР и значительно проигрывает лидирующей по показателю инвестиции в основной капитал Воронежской области.

Анализ показал значительный разрыв между максимальным и минимальным значением данного показателя у регионов ЦФО: в 2019 году максимальное значение показателя было больше минимального в 7,6 раз. Речь идет об отношении значений показателей двух субъектов РФ - Московской области и Костромской области. Ивановская область занимает 17 место в округе по абсолютному показателю инвестиций в основной капитал (42904 рублей), Рязанская - 15-е (51251 рублей), а Тверская - 14-е (56339 рублей). В интервале между 60-70 тыс рублей находятся показатели пяти областей ЦФО - Брянская область, Владимирская область, Смоленская область, Ярославская область и Орловская область. Данные субъекты РФ демонстрируются аналогичный абсолютный прирост показателя в 2010-2019 гг.
(50-70 тыс рублей), в то время как показатели лидеров округа выросли на 100-140 тыс рублей (за исключением Москвы, чей прирост составил 266072 рубля).

В ЦФО в 2010-2019 гг. доля инвестиций в основной капитал в ВРП оставалась на уровне 15,3-18,5\%. На рисунке 5 представлены показатели отношения инвестиций в основной капитал к ВРП регионов ЦФО. Самый высокий показатель в 2019 году у Воронежской области (29,8\%). Самый низкий - у аутсайдера - Костромской области (12,8\%). В «необходимом» для поступательного роста экономики в 3-4\% интервале (25\%) находятся показатели инвестиций пяти областей из 18-ти (Воронежская область, Курская область, Липецкая область, Тульская область, Тамбовская область). Остальные регионы недоинвестируют экономику на 5-7\%. У 15 -ти регионов наблюдаются отрицательные темпы прироста показателей в период 2010-2019 гг. (за исключением Москвы, Московской и Курской областей).

Согласно данным Росстата, инвестиционная активность в ЦЧР характеризуется относительно не высокими долями средств бюджета в общем объеме инвестиций. В сравнении с 2010 годом в 2019 году доля бюджетных инвестиций снизилась в округе с 19,47 до $21,03 \%$ (на уровне других регионов ЦФО кроме Москвы), что выше этого показателя по РФ и ЦФО.

Удельный вес привлекаемых средств в инвестициях ЦФО значительно снизился по сравнению с уровнем 2010 года: с 60,6\% до 49,5\%. В ЦФО этот показатель был одним из самых высоких по РФ. Рост доли собственных средств в период 2010-2019 гг. в ЦЧР также положительный. Наиболее высокий показатель собственных 


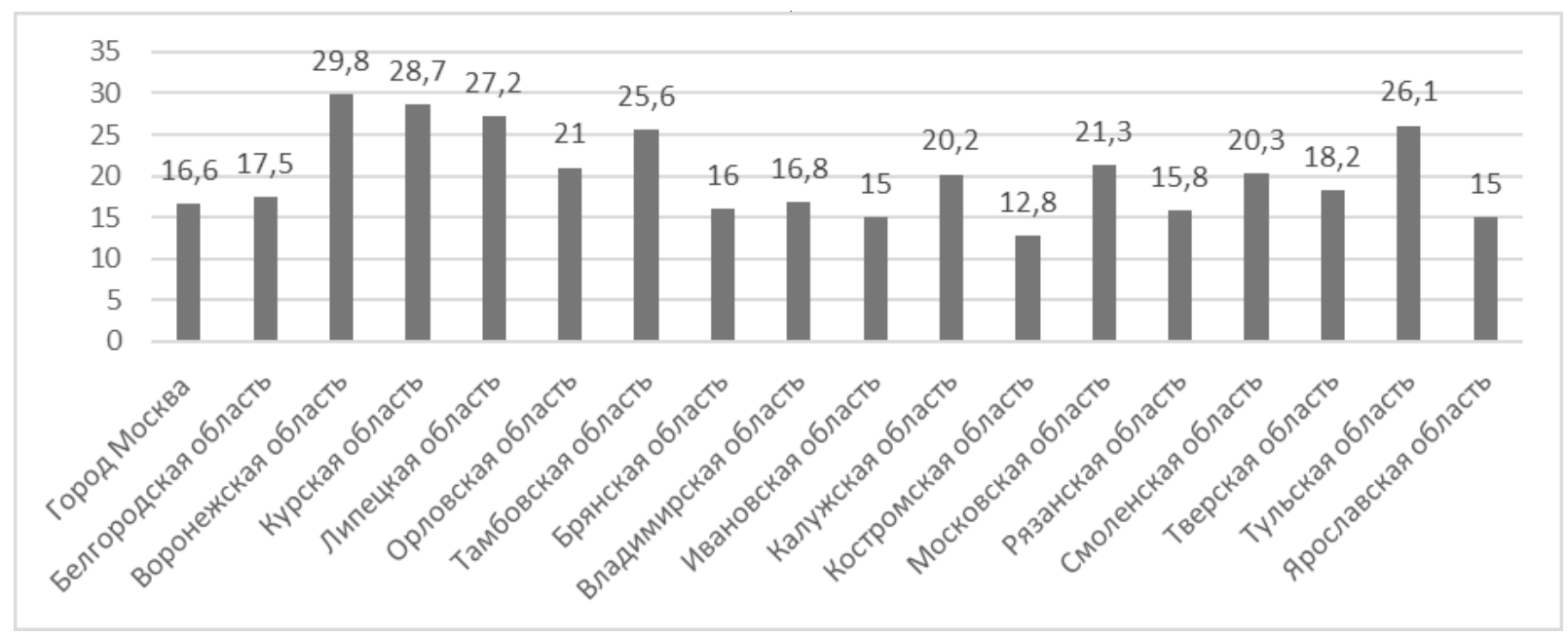

Рис. 5. Отношение объема инвестиций в основной капитал к валовому региональному продукту, в \%, 2019 год

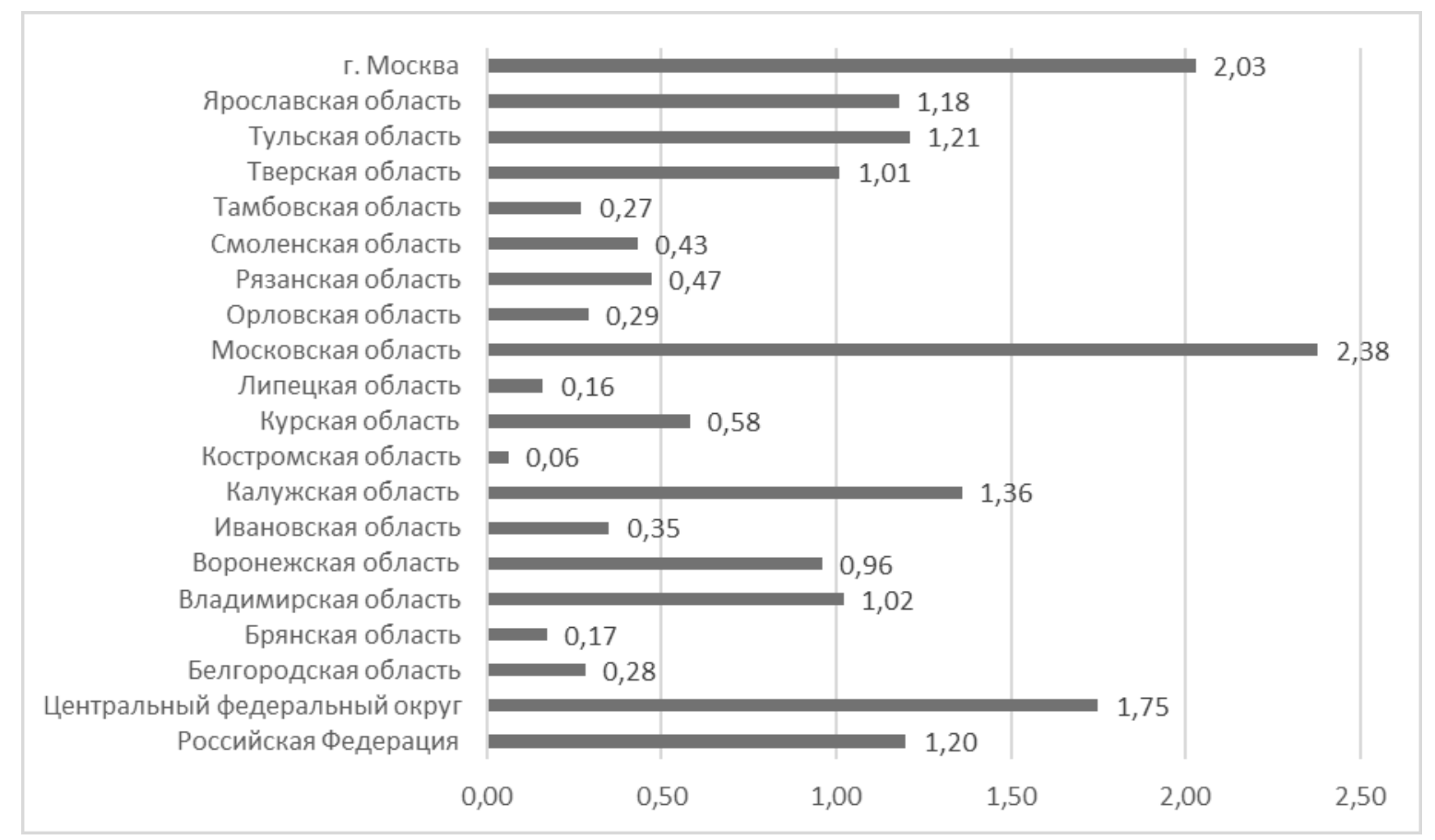

Рис. 6. Доля внутренних затрат на исследования и разработки, в \% к ВРП, 2019 год

средств у Липецкой области (65,5\%). С небольшим отставанием за ней следует Белгородская область со значением показателя в 60,4\%. У Воронежской области данный показатель значительно ниже - 47,2\%.

Автором были проанализированы показатели инвестиций в основной капитал по формам собственности, представленные Росстатом в сборниках [8-13]. Согласно расчетам автора, государственные инвестиции ЦФО остаются низкими с трендом к росту (с 17,7\% до 19,3\%). В 2019 году в регионах ЦЧР доля частных инвестиций варьировалась в промежутке 57,5-78,0\%. Наименьшее значение показателя характерно для Тамбовской области, а наибольшее - для Белгородской области. Даже наименьший показатель остается на уровне показателя ЦФО. В Центральном регионе наиболее высокий уровень государственных инвестиций в Москве (24,7\%), Воронежской, Костромской и Тверской областях (20- 


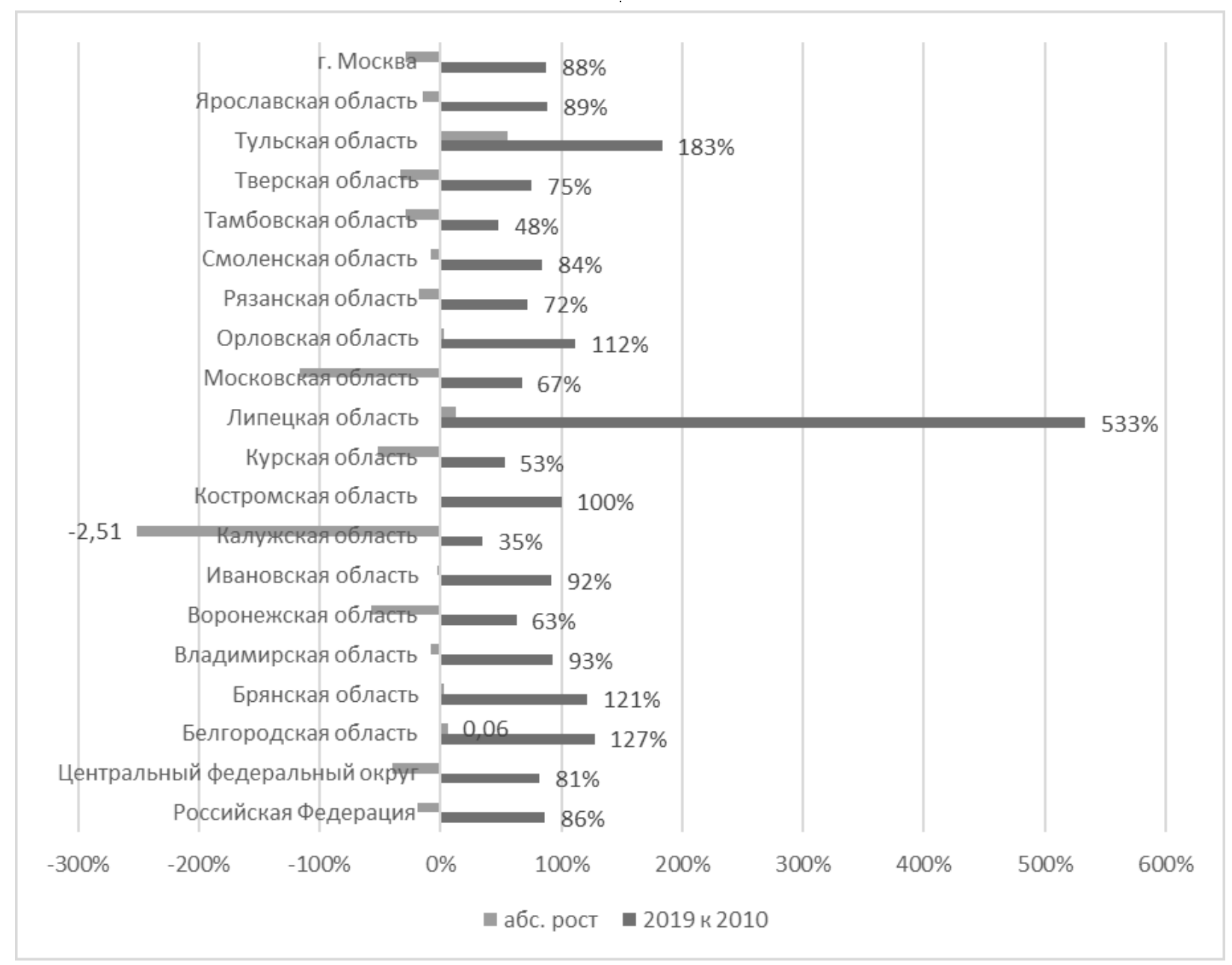

Рис. 7. Показатели динамики внутренних затрат на исследования и разработки в \% к ВРП

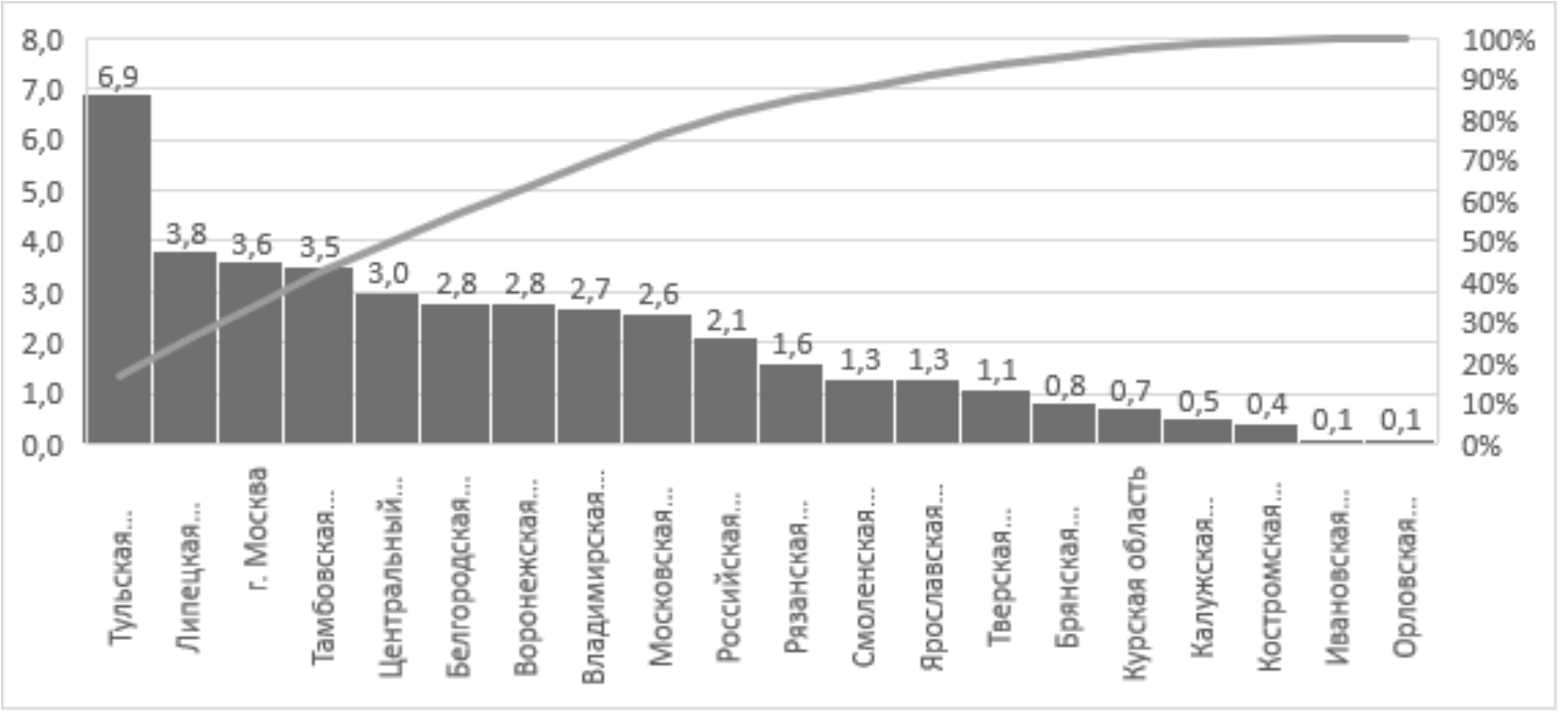

Рис. 8. Доля затрат на инновационную деятельность, в общем объеме отгруженных товаров, 2019 год, в \% 


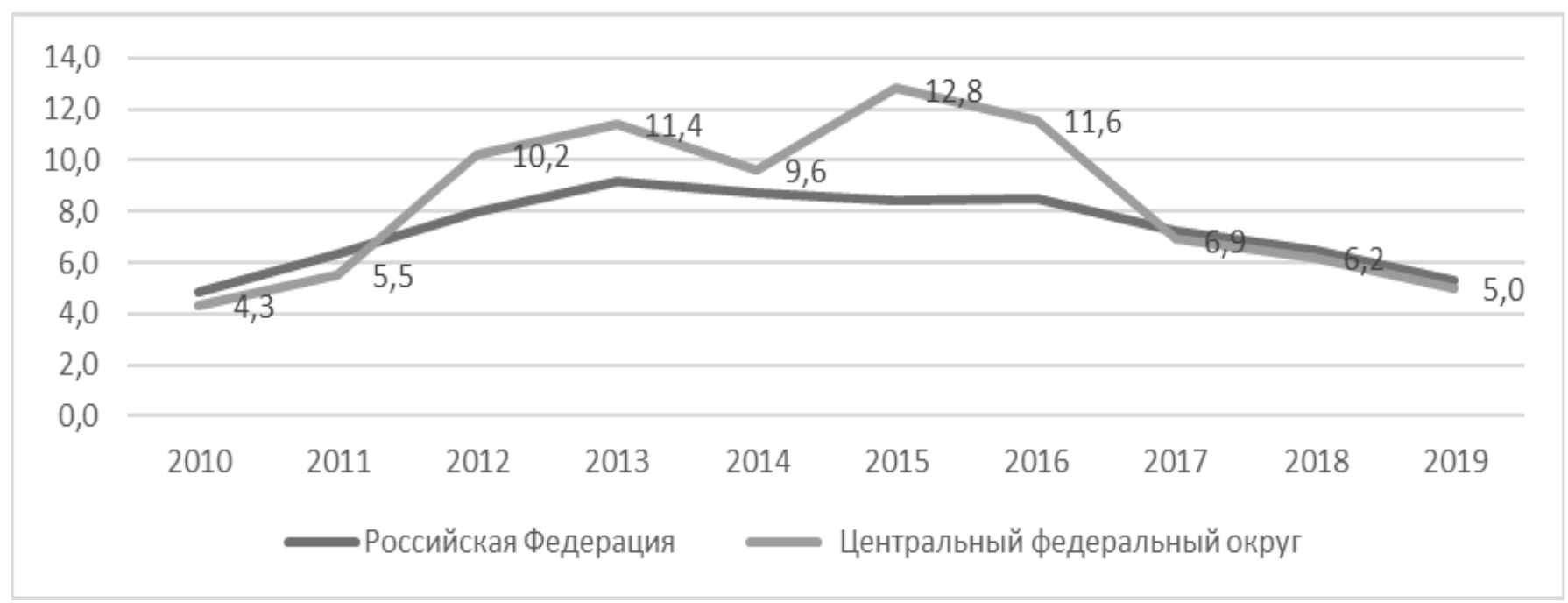

Рис. 9. Удельный вес инновационных товаров в общем объеме отгруженных товаров, в \%

21\%). Частные инвестиции в 2019 году составляют более $50 \%$ инвестиций 9-ти областей (табл. 3), и более $70 \%$ - инвестиций Ивановской области.

\section{Инвестиции в инновации}

Анализ показал, что расходы на исследования и разработки (НИОКР) в регионах ЦФО (кроме Москвы и Московской области, рис. 6) отстают от расходов в РФ и чрезмерно зависят от отдельных секторов промышленности. Регионы ЦФО рискуют постепенно потерять конкурентоспособность из-за медленных инноваций, внедрения цифровых технологий и роста производительности, что контрастирует с быстрыми технологическими изменениями и появлением новых игроков на внутренних и внешних рынках.

Более того, наблюдается отрицательный рост данного показателя в исследуемый период у 14 из 18 регионов ЦФО (рис. 7). Ничтожно малыми (менее 0,1\%) остается доля внутренних затрат на исследования и разработки, в\% к ВРП в Костромской области. Менее 0,5\% этот показатель у восьми областей. Между лидерами и аутсайдерами рейтинга наблюдается разница показателей более 1 пункта.

Доля затрат на инновационную деятельность, в общем объеме отгруженных товаров, выполненных работ, услуг остается не только низкой, но и крайне неоднородной в округе (рис. 8). Такие регионы как Орловская область, Ивановская область, Костромская область, Калужская область, Курская область, Брянская область отстают от «регионов-лидеров» на более, чем 4 пункта. Лидер 2019 года - Тульская область - с показателем 6,9\% обогнал Москву, Липецкую и Тамбовскую области на 3,1-3,4\%.
Хроническое недофинансирование инновационной деятельности в ЦФО приводит к низким показателям выпуска инновационной продукции (рис. 9). В округе удельный вес инновационных товаров, работ, услуг в общем объеме отгруженных товаров, выполненных работ, услуг в 2010-2019 гг. не превышал 13\%. Последнее десятилетие этот показатель оставался на уровне выше РФ в 2-2,5 раза, но с 2015 года снизился с 12,8 до $5,0 \%$.

Удельный вес инновационной продукции в регионах ЦФО представлен на рисунке 10.

Лидер рейтинга по абсолютному значению показателя - Белгородская область (13,9\%). Абсолютные аутсайдеры - Орловская область $(0,5 \%)$ и Ивановская область (0,6\%). Следует отметить, что значения данного показателя в рассматриваемый период остаются крайне нестабильными даже у регионов, которых можно назвать передовыми. На рисунке 11 представлена динамика анализируемых показателей для пяти регионов-лидеров ЦФО 2019 года. Восходящий тренд за период наблюдений отмечается только у Рязанской области. Показатели Белгородской, Воронежской, Тульской, Ярославской областей волатильны. Рост показателя Белгородской области сменился спадом в 2018 году, как и рост показателя Ярославской области.

\section{Зак^ючение}

Регионам необходимо преодолеть замедление темпов роста и приступить к реализации долгосрочной стратегии, направленной на обеспечение устойчивого роста и развития. На данном этапе целесообразно 


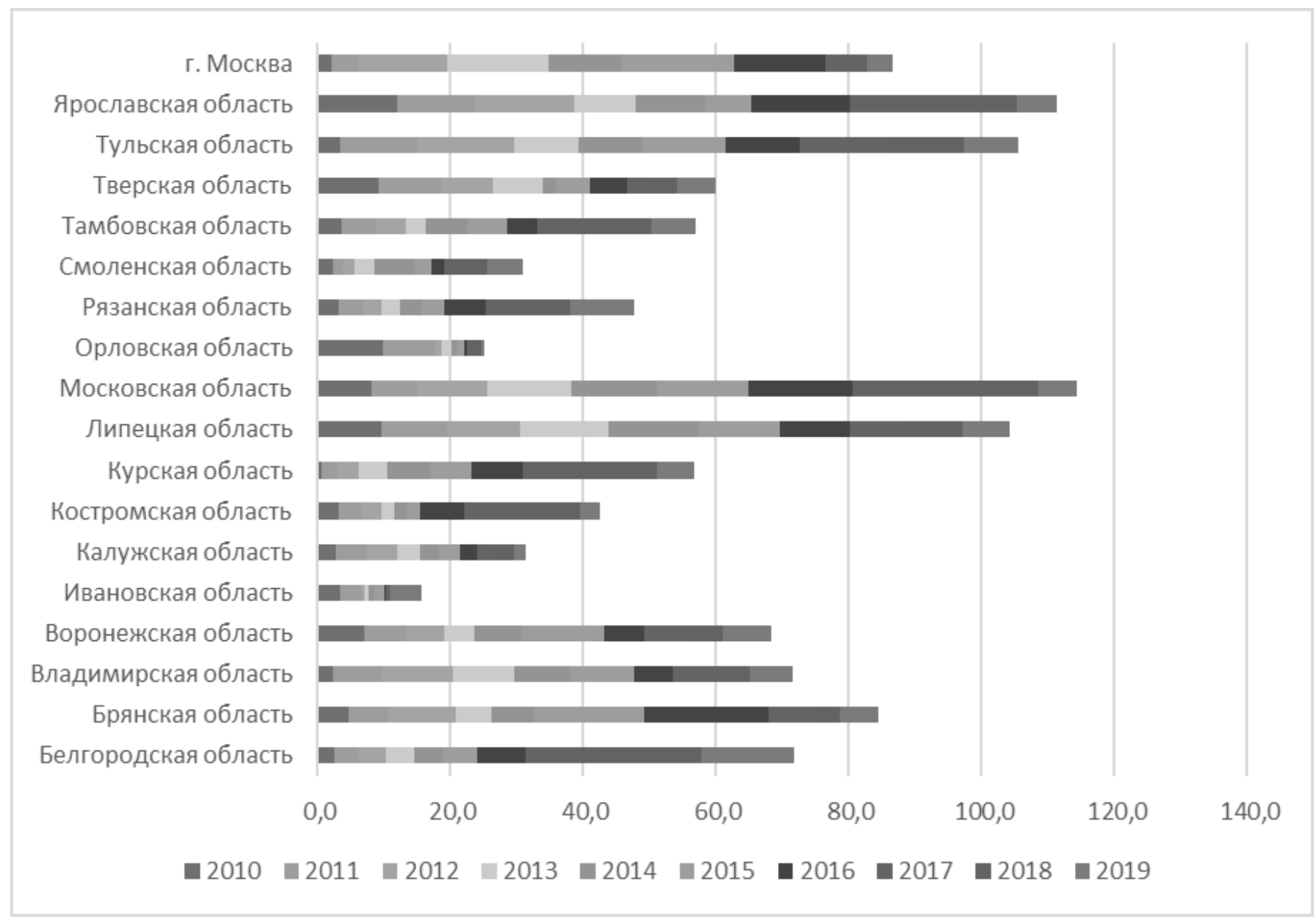

Рис. 10. Удельный вес инновационных товаров в общем объеме отгруженных товаров, 2010-2019 гг., в \%

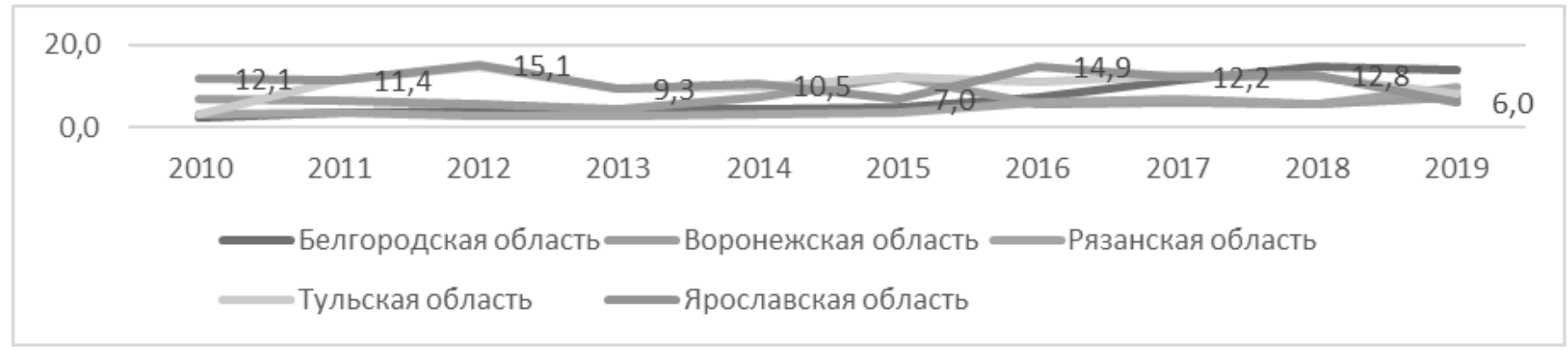

Рис. 11. Удельный вес инновационных товаров в общем объеме отгруженных товаров, выполненных работ, услуг, в \%

воспользоваться возможностью низких процентных ставок для поддержки своих усилий не только с точки зрения краткосрочного стимулирования, но и реализации следующих приоритетных мер:

จ рост инвестиций для улучшения условий устойчивого и инклюзивного роста;

- создание благоприятных условий для частных инвестиций, чтобы ускорить преобразования.
В этой связи несколько тенденций, выявленных в процессе исследования, вызывают нашу озабоченHOCTь.

В 2010-2019 году неравенство в инвестициях между регионами практически не сократилось. На примере ЦФО были выявлены значительные диспропорции финансового обеспечения инвестиционных процессов. 
70\% инвестиций округа сосредоточено только в двух регионах ЦФО - Москва и Московская область. 16 регионов округа аккумулируют остальные 1760877 млн. рублей, но значительная неоднородность по всем показателям наблюдается и внутри этой когорты. По некоторым показателям отрыв регионов-аутсайдеров (Костромская, Ивановская, Орловская области) от лидеров (Тульская область и иные регионы Центрально-черноземного округа) - до 3-4 раз. Значения индексов всех показателей в регионах округа демонстрируют периодические колебания, отражающие периоды волатильности на макроэкономическом уровне. Даже лидеры нашего рейтинга демонстрируют крайне низкие показатели активности в сфере использования инвестиций - внутренних затрат на исследования и разработки, затрат на инновационную деятельность, а также удельного веса инновационных товаров в общем объеме отгруженных товаров, выполненных работ, услуг.

На этом фоне изменения в технологии и структуре экономики приводят к концентрации все большей экономической активности и высококвалифицированные рабочие места в мегаполисах. Экономический динамизм Москвы может положительно повлиять на экономический рост округа, но растущее пространственное неравенство, которое усугубляется снижением инвестиций в инфраструктуру в менее благополучных регионах ЦФО, может отразиться на растущем неравенстве в доходах результатах инновационного развития.

На основании проведенного исследования можно заключить о низкой степени вероятности выравнивания в географическом распределении инвестиций в основной капитал, а также удельного веса инвестиций В инновации в регионах ЦФО в среднесрочной пер- спективе. Доля инвестиций в основной капитал в ВВП регионов ЦФО находится в диапазоне 12,8-29,8\%. Для перехода к устойчивому долгосрочному росту в 3-4\%, 13-ти областям ЦФО значение показателей инвестиций в ВВП предстоит повысить до $25 \%$.

Государственные инвестиции ЦФО остаются низкими с трендом к росту (с 17,7\% до 19,3\%). Осуществление государственных инвестиций имеет важное значение для улучшения условий устойчивого и инклюзивного роста в регионах округа. На фоне глобального замедления и там, где это позволяет бюджет, государственные инвестиции должны быть приоритетными, при этом приоритет должен отдаваться расходам, способствующим росту.

Прямые государственные инвестиции должны дополняться мерами по устранению барьеров и несогласованных стимулов, сдерживающих инвестиции частного сектора. Таким образом, быстрые реформы смогут противодействовать экономическому спаду и способствовать инновациям, инвестициям в бизнес, необходимым для повышения производительности и достижения долгосрочной конкурентоспособности и устойчивости. Государственные и частные инвестиции следует рассматривать как взаимодополняющие, при этом целенаправленные государственные инвестиции создают катализатор возможности для частных инвестиций.

Следует наращивать государственные инвестиции в НИОКР с большей поддержкой инноваций и инвестиций в нематериальные активы, такие как программное обеспечение и базы данных, обучение сотрудников, совершенствование бизнес-процессов и совершенствование методов управления.

\section{ЛИТЕРАТУРА}

1. Kvon G.M., Faleeva L.V., Pyrkova G.K., Alyakina D.P., Mustafina A.A., Kryukova N.I., Blekus V.V. Strategis priorities of regional investment activity // Eurasian Journal of Analytical Chemistry. 2017. № 12(7B), pp. 1099-1106.

2. Прогноз социально-экономического развития Российской Федерации на период до 2024 года. Минрегионразвития. [Электронный ресурс]. URL: https://economy.gov.ru/material/file/450ce3f2da1ecf8a6ec8f4e9fd0cbdd3/Prognoz2024.pdf (дата обращения: 16.06.2021).

3. Аналитический центр при Правительстве РФ. Динамика инвестиций в основной капитал на фоне пандемии COVID-19. Бюллетень 0 текущих тенденциях российской экономики ноябрь 2020. Выпуск № 67, ноябрь 2020. [Электронный ресурс]. https://ac.gov.ru.

4. Доклад РСПП о состоянии делового климата в 2020 году [Электронный ресурc]. URL: https://media.rspp.ru/document/1/0/ a/0a140bd76442296880d5190932d0bf73.pdf (дата обращения: 23.06.2021).

5. Поздняков К.К. Тенденции и перспективы развития российского банковского сектора и его воздействие на региональную финансовую систему // Проблемы экономики и юридической практики. 2021. Т. 17. № 2. С. 95-101.

6. Porter M.E. The Competitive Advantage of Nations // Harvard Buisness Review. 1990. March — April. P. 73-93.

7. Burtseva T.A. (November 5th 2018). Statistical Research of Investment Appeal of Russian Regions, Statistics — Growing Data Sets and Growing Demand for Statistics, Türkmen Göksel, Intech0pen, D0I: 10.5772/intechopen.75465. Available from: https://www.intechopen.com/chapters/60246.

8. Регионы России. Социально-экономические показатели. 2017 [Электронный ресурс]. URL: https://rosstat.gov.ru/storage/mediabank/peg-pok17.pdf (дата обращения: 09.04.2021). 
9. Регионы России. Социально-экономические показатели. 2018 [Электронный ресурc]. URL: https://rosstat.gov.ru/storage/mediabank/Reg-pok18.pdf (дата обращения: 08.04.2021).

10. Регионы России. Социально-экономические показатели. 2019 [Электронный ресурс]. URL: https://rosstat.gov.ru/storage/mediabank/1dJJCOvT/Region_ Pokaz_2019.pdf (дата обращения: 09.04.2021).

11. Регионы России. Социально-экономические показатели. 2020 [Электронный ресурс]. URL: https://rosstat.gov.ru/storage/mediabank/LkooETqG/Region_ Pokaz_2020.pdf (дата обращения: 12.04.2021).

12. Регионы России. Социально-экономические показатели. Инвестиции, 2015 [Электронный ресурc]. URL: https://gks.ru/bgd/regl/B15_14p/Main.htm (дата обращения: 11.04.2021).

13. Регионы России. Социально-экономические показатели. Инвестиции, 2016 [Электронный ресурc]. URL: https://gks.ru/bgd/regl/B16_14p/Main.htm (дата обращения: 11.04.2021).

( П Поздняков Константин Константинович ( KKPozdnyakov@fa.ru ).

Журнал «Современная наука: актуальные проблемы теории и практики»

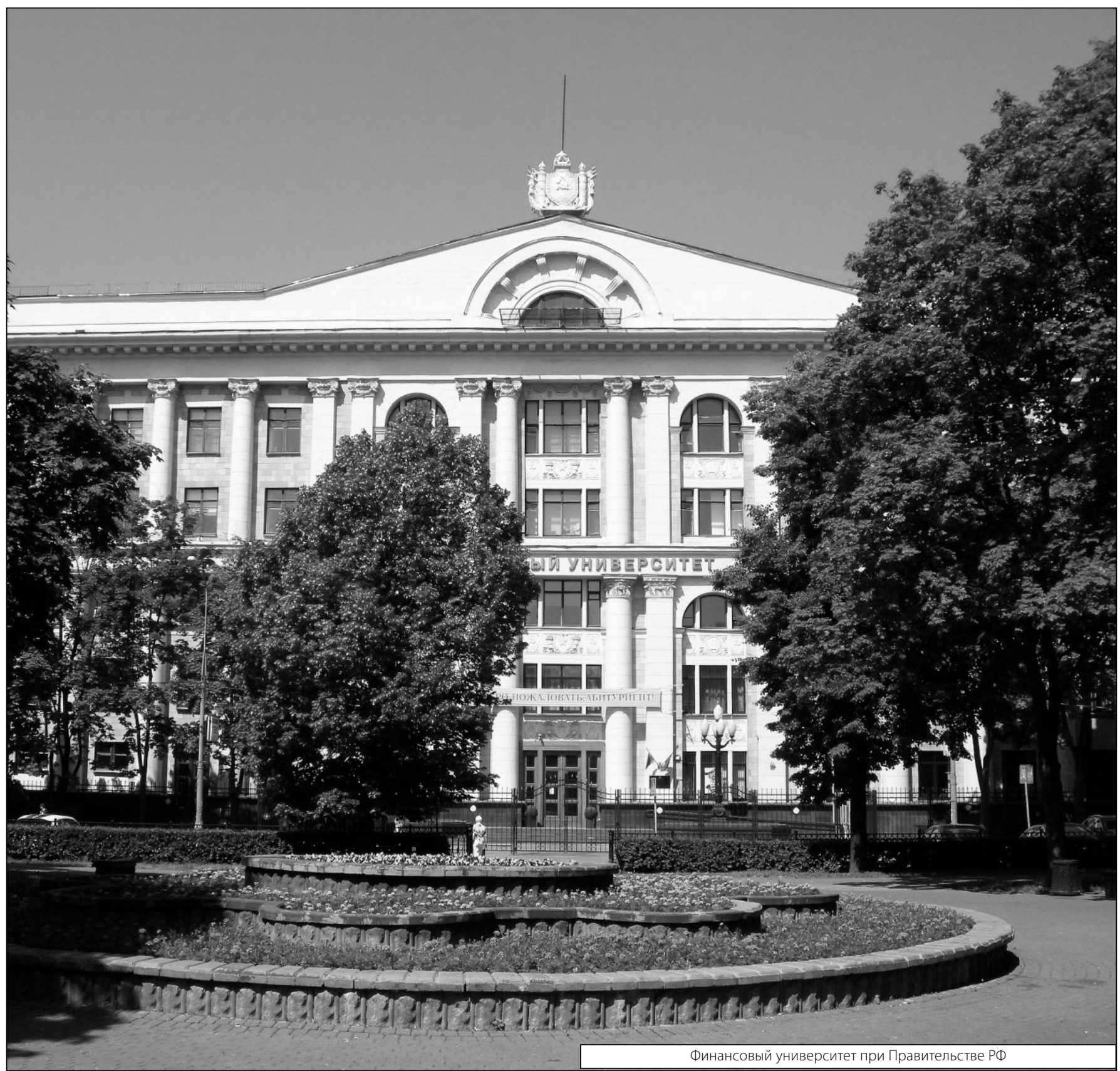

